\title{
Bitkilerde Melatonin ve Üstlendiği Görevler
}

\author{
Gökçen YAKUPOĞLU1(D, Şebnem KÖKLÜ2@ Ahmet KORKMAZ2 \\ ${ }^{1}$ Bozok Üniversitesi Boğazlıyan Meslek Yüksek Okulu, Tıbbi Aromatik Bitkiler Programı, Yozgat, \\ ${ }^{2}$ Kahramanmaraş Sütçü İmam Üniversitesi, Ziraat Fakültesi, Bahçe Bitkileri Bölümü, Kahramanmaraş \\ $\triangle:$ akorkmaz@ksu.edu.tr
}

\begin{abstract}
ÖZET
Önceleri sadece hayvansal bir hormon olarak bilinen melatoninin bitkilerde de var olduğunun keşfinden sonra bu molekül üzerinde sayısız araştırma yapılmıştır. Yapılan araştırmalar, melatoninin bugüne kadar üzerinde analiz yapılan hemen tüm bitki türlerinde var olduğunu ve hayvanlardakine benzer görevler üstlendiğini ortaya koymuştur. Melatoninin bitkilerde üstlendiği en belirgin rolleri arasında sirkadiyen ritmi, büyümeyi ve gelişmeyi düzenlemek ve çok çeşitli çevresel stres faktörlerine karşı toleransı arttırmak sayılabilir. Araştırma sonuçları stres faktörlerine maruz kalan bitkilerde içsel melatonin seviyesinin yükseldiği ve yeterli melatonin üretmeyen bitkilerde dışarıdan yapılan melatonin uygulamaları yoluyla strese karşı toleransın iyileştirilebileceğini ortaya koymuştur. Ayrıca son yıllarda genetik mühendisliği yöntemleri kullanılarak çok yüksek seviyelerde melatonin üreten ürün hatları geliştirilmiştir. Bu derlemede bitkilerde melatoninin keşfi, dağılımı ve stres altındaki bitkilerde üstlendiği görevler hakkında detaylı bilgi verilecektir.
\end{abstract}

\section{Phytomelatonin and Its Roles in Plants}

\begin{abstract}
Since its discovery in plants, extensive research has been conducted on melatonin which was formerly known to be a hormone existed exclusively in animals. Studies have shown that melatonin was indeed present in every plant species tested and that it had similar roles as in animals. Main roles of phytomelatonin are to regulate circadian rhythm as well as growth and development and to enhance tolerance to various environmental stress factors. Evidence indicates that plants living under stressful environments have higher melatonin contents compared to those live under normal conditions and that exogenous application of melatonin can also improve stress tolerance of plants that do not produce enough melatonin endogenously. Additionally, new lines in some crop species that possess excessive melatonin production traits have recently been developed through genetic engineering. This review mainly focuses on the discovery of melatonin in plants, its distribution among plant species and on the regulatory effects of melatonin when plants confront with harsh environmental conditions.
\end{abstract}

\section{DOI:10.18016/ ksudobil.320180}

\section{Makale Tarihçesi}

Geliş Tarihi : 09.06.2017

Kabul tarihi : 19.08.2017

Anahtar Kelimeler
melatonin,
abiyotik stres,
bitki büyüme düzenleyici,
antioksidan,
sirkadiyal ritim

\section{Derleme Makale}

\section{Article History \\ Receive : 09.06.2017 \\ Accepted : 19.08.2017}

\author{
Keywords \\ melatonin, \\ abiotic stress, \\ plant growth regulation, \\ antioxidant, \\ circadian rhythm
}

\section{Review Article}

To cite : Yakupoğlu G, Köklü Ş, Korkmaz A 2018. Bitkilerde Melatonin ve Üstlendiği Görevler KSÜ Tarim ve Doğa Derg 21(2):264-276. DOI:10.18016/ ksudobil.320180

\section{Melatoninin Bitkilerde Keşfi ve Dağılımı}

Bir indolamin triptofan türevi olan melatoninin, $N^{-}$ acetyl-5-methoxytryptamine, sığır beyin üstü bezi (epifiz) dokusunda 1950'lerin sonlarında tanımlanması bilim dünyası için büyük bir keşif olmuştur (Lerner ve ark., 1958). Bu gün neredeyse her organizmada var olduğu belirlenen ve canlı organizmalarda düşük molekül ağırlığına ve basit bir yapıya sahip olan melatonin, epifiz bezinin ışığa duyarlı pineolasit adı verilen hücrelerinden salgılanır ve bakterilerden memelilere farklı türlerde pleyiotropik biyolojik aktiviteler sergiler (Hardeland ve ark., 2000). Molekül formülü $\mathrm{C}_{13} \mathrm{H}_{16} \mathrm{~N}_{2} \mathrm{O}_{2}$ ve molekül ağırlığı 232,28 $\mathrm{g} \mathrm{mol}^{-1}$ (Anonim, 2015) olan melatoninin kimyasal yapısı Şekil 1'de görülmektedir. 


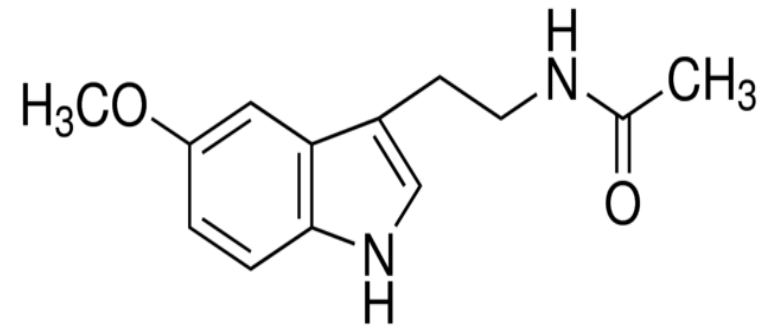

Şekil 1. Melatoninin kimyasal yapısı (Anonim, 2015)

Melatoninin ilk olarak alglerde keşfedilmesiyle (Poeggeler ve Hardeland, 1994) farklı bitkilerin dokularinda da bulunabileceği düşüncesi ortaya atılmıştır. Bitkilerde melatonin ilk olarak, 1995 yılında iki ayrı çalışma grubunun birbirinden bağımsız yaptığı çalışmalar sonucunda bulunmuştur (Dubbels ve ark., 1995; Hattori ve ark., 1995). Daha sonra yapılan çalışmalarda pek çok bitki türünün tohumları, meyveleri, yaprakları ve köklerinde oldukça yüksek miktarlarda melatonin bulunduğu saptanmıştır (Reiter, 1999; Tettamanti ve ark., 2000; Reiter ve ark., 2007). Bitkilerde var olduğunun ortaya konmasından sonra giderek artan sayıda yürütülen araştırmalarda melatoninin çok çeşitli sebze, meyve, tohum, tahıl, tıbbi ve aromatik bitkiler ile süs ve yabani bitki türlerinde bulunduğu bildirilmiştir (Paredes ve ark., 2009; Arnao, 2014; Feng ve ark., 2014).

Bitkilerde bulunan melatonin miktarının sadece türden türe farklılık göstermekle kalmadığı, aynı zamanda aynı türün içerisindeki genotipler veya çeşitler arasında veya aynı genotipteki bireylerinin farklı büyüme evreleri içinde de farklılık gösterdiği bildirilmiştir (Dubbels ve ark., 1995; Hattori ve ark., 1995; Posmyk ve Janas, 2009). Örneğin, yeşil domates meyvelerinde melatonin içeriğinin düşük düzeyde olmasına rağmen, olgun ve kırmızı renkli meyvelerde ise yüksek miktarlarda bulunduğu saptanmıştır (Van Tassel ve ark., 2001). Farklı biber ve domates çeşitlerinin meyvelerinin melatonin içeriklerinin araştırıldığı bir çalışmada, biber çeşitlerinde melatonin içeriği 31,0-93,4 ng g-1arasında değişirken, domates çeşitlerinde 7,47-249,98 $\mathrm{ng} \mathrm{g}^{-1}$ olarak tespit edilmiştir (Riga ve ark., 2014). Aynı araştırmada bazı biber çeşitlerinde yeşil meyvelerde melatonin içeriği daha yüksek bulunurken, bazı çeşitlerde ise kırmızı meyvelerde melatonin içeriği daha yüksek bulunmuştur. Çin kökenli tıbbi bitkilerin bir çoğunun (>1000 ng $\mathrm{g}^{-1}$ ) ve sızma zeytin yağının da yüksek miktarlarda melatonin içerdiği bildirilmiştir (Chen ve ark., 2003; De la Puerta ve ark., 2007). Bu bitkilerin yaşlanmayı geciktirici ve özellikle sinir sistemi bozuklukları gibi hastalıkları tedavi etme özelliklerinin, melatoninin ileride bahsedilecek olan antioksidan özelliklerinden kaynaklandığı tahmin edilmektedir.

Yapılan araştırmalar aynı bitki içerisinde bitki gelişime evrelerine bağlı olarak da melatonin içeriğinin önemli ölçüde değiştiğini ortaya koymuştur. Örneğin, iki farklı biber çeşidinde farklı aşamalarda (çimlenme, fide, çiçeklenme ve hasat) ve farklı organlarında (yaprak, kök, meyve ve tohum) melatonin içeriğinin belirlendiği bir araştırmada, kotiledon aşamasındaki fidelerde yüksek seyreden melatonin seviyesinin bitki olgunlaştıkça düştüğü bulunmuştur (Korkmaz ve ark., 2014). Araştırıcılar, bitki gelişim evrelerinin ilerlemesiyle biber yapraklarında ve köklerinde melatonin seviyesinin azaldığını, buna karşılık meyvelerin olgunlaşması (kızarması) ile meyve ve tohumlarda melatonin seviyelerinin önemli ölçüde arttığını ve tüm bunların da melatoninin bu gelişim süreçlerinin kontrol edilmesinde görev aldığını belirtmişlerdir. Yapraklarda ve köklerde bitkilerin gelişim evrelerinin ilerlemesiyle (yaşlanmaya bağlı olarak) melatonin içeriğinin düşmesi patlıcanda da görülmüş ve bu durumun yapraklarda ve köklerde bulunan melatoninin çiçek ve meyve gibi üreme organlarına oksidatif streslere karşı koruma amaçlı ihraç edildiği fikrini ortaya atmışlardır (Korkmaz ve ark., 2017a).

Bitki organları arasında genelde en fazla melatonin içeriğine tomurcuk ve çiçek gibi generatif organlar ile meyve ve tohumlar sahiptirler. Bunun özellikle tomurcuklarda ve kurumuş tohumlarda melatoninin antioksidan savunma mekanizmasında görev yapmasından kaynaklandığı düşünülmektedir (Paredes ve ark., 2009; Posmyk ve Janas, 2009). Örneğin ceviz tohumunda yüksek miktarda melatonin bulunmasının nedeninin yağ asitlerinin oksidasyonunu engellemek ve sonrasinda da tohumun çimlenme kapasitesini yitirmeden uzun süre canlı kalmasını sağlamak olduğu bildirilmiştir (Reiter ve ark., 2005; Iriti ve Faoro, 2006). Ayrica hem suda hem de yağda eriyebilen bir madde olması (amphiphility) dolayısıyla özellikle yüksek oranda yağ ihtiva eden tohumların melatonin içeriğinin daha fazla olduğu ve bu özelliği ile de tohumları dormansi veya kurumuş halde antioksidan enzimlerin yokluğunda veya yetersizliğinde koruyarak yüksek oranda çimlenme göstermelerine yardımcı olduğu bildirilmiştir (Hardeland ve ark., 2007). Boru çiçeği (Datura meteঠ) bitkisinin çiçeklerinde melatonin seviyesinin değişimini tespit etmek amacıyla farklı gelişme aşamalarda toplanmış çiçek tomurcuklarının melatonin içeriklerin incelendiği bir araştırmada, en yüksek melatonin seviyesinin yeni gelişmeye başlamış (en küçük) tomurcuklarda olduğu bulunmuş ve çiçek tomurcuğunun gelişiminin ilerlemesiyle melatonin içeriğinin önemli miktarda azalış gösterdiği tespit edilmiştir (Murch ve ark., 2009). Domateste farklı olgunluk aşamalarında meyve ve yapraklarda melatonin içeriği incelenmiş ve yapraklar yaşlandıkça melatonin seviyesinin azaldığı, meyve olgunlaştıkça ise meyve eti ve tohumlarda melatonin seviyesinin arttığı bildirilmiştir (Okazaki ve Ezura, 2009). Yine 
biberde ve patlıcanda farklı aşamalarda ve farklı organlarda melatonin içeriğinin belirlendiği çalışmalarda yeni çimlenmiş fidelerde, çiçeklerde ve tohumlarda oldukça yüksek miktarlarda melatonin tespit edilmiştir (Korkmaz ve ark., 2014; Yakupoğlu, 2016). Aynı araştırmalarda biber ve patlıcan meyvelerinin farklı büyüme aşamalarında melatonin değişimi de ortaya konmuş ve çiçeklenmeden sonra melatonin içeriğinin gelişen meyvelerde önce azaldığını fakat meyvelerin olgunlaşması birlikte tekrar artış gösterdiği de bildirilmiştir.

\section{Melatonin Biyosentezi}

Bitkiler, hayvanlar, algler ve bakteriler de dahil olmak üzere tüm canlılarda melatonin sentezi aromatik bir aminoasit olan triptofan (Trp)'dan başlar. Trp sadece melatoninin değil, tüm bitki ve hayvanlarda bulunan bir bileşik olan serotonin (Ser) ve yine bitkisel bir hormon olan indol-3-asetik asitin (IAA) de sentezinin başladığı bir maddedir. Bitkilerdeki melatonin sentezi, hayvanlardakine benzer bir yol izlemektedir ve normal koşullar altında yetişen ya da genç bitkilerde ardışık dört enzimatik basamak izleyerek triptofan/triptamin/serotonin/N-

asetilserotonin/melatonin sırasıyla gerçekleşir (Şekil 2, I nolu iz yolu). Ancak yapılan son araştırmalarla birlikte özellikle yaşlanmadan dolayı yüksek miktarlarda serotonin üretiminin söz konusu olması durumunda melatonin biyosentezinin triptofan/triptamin/serotonin/5-

metoksitriptamin/melatonin sırasıyla gerçekleştiği ortaya konmuştur (Şekil 2, II nolu iz yolu, Back ve ark., 2016). Bitkilerde melatonin sentezi sirasinda görev alan ve her bir ara maddenin oluşumunu katalize eden enzimler triptofan dekarboksilaz (TDC), triptofan hidroksilaz (T5H), serotonin N-asetiltransferaz (SNAT), N-asetilserotonin, methiltransferaz (ASMT) ve kafeik asit O-methiltransferaz (COMT) enzimleridir.

Normal koşullar altında yetişen bitkilerde ilk aşamada TDC enziminin katalize etmesi sonucu Trp triptamine dönüşür. Çeltikte (Kang ve ark., 2008), biberde (Park ve ark., 2009), pervane çiçeğinde (Catharanthus roseus) (De Luca ve ark., 1989) ve tütün bitkisinde (Fiore ve ark, 2002) yapılan çalışmalarla TDC enzimi klonlanmıştır. TDC, melatonin sentezinde kisitlayıcı olan enzimlerden biridir çünkü bitkilerde bu enzimin ifade seviyesinin çok düşük değerlerde seyrettiği bildirilmiştir (Zhao ve ark., 2012). Triptaminden serotonine dönüşümü gerçekleştiren ve biyosentez iz yolun ikinci basamağını katalize eden enzim olan T5H enzimi çeltik bitkisi üzerinde yapılan çalışmalarla tanımlanmıştır (Kang ve ark., 2013). Serotonin, bitkilerde melatonin biyosentezinin gerçekleşmesinde mutlaka gerekli olan bir ara maddedir (Back ve ark., 2016). Melatoninin biyosentez iz yolu üzerinde görev alan son iki enzim serotoninin N-asetilseratonine dönüşümünü düzenleyen AANAT/SNAT ile $\mathrm{N}$-asetilserotoninin melatonine dönüşünümü kontrol eden HIOMT/ASMT enzimleridir. Triptamin oluşumunda görev alan TDC enziminin varlığ $\breve{g}_{1}$ ya da aktivitesinin yüksekliği melatonin sentezinde belirleyici olduğu bilinmekle beraber melatonin seviyesini kesin olarak belirleyen enzimin (rate-limiting enzyme) HIOMT/ASMT olduğu bildirilmiştir (Byeon ve ark., 2014). Melatonin sentezinde görev alan HIOMT enziminin aktivitesinin sıcaklığın yükselmesi ile birlikte artarak 50-55 ${ }^{\circ}$ C'lerde maksimuma ulaştığı; ancak açık arazi koşullarında sıcaklıktaki artışın genelde artan ışıktan kaynaklanması dolayısıyla da bitki içerisindeki içsel melatonin seviyesinin düşük seyrettiği bildirilmiştir (Byeon ve Back, 2014).

Melatonin biyosentez yolundaki enzim reaksiyonlarının sırası ara maddenin hücre içi yerini ve melatonin oluşumunu değiştirmektedir. Melatonin sentezinin, görev alan son enzim SNAT olduğunda kloroplastlarda (II nolu izyolu), COMT/ASMT olduğunda ise sitoplazmada (I nolu izyolu) gerçekleştiği bildirilmiştir (Back ve ark., 2016).

\section{Triptofan $\longrightarrow$ Triptamin $\longrightarrow$ Serotonin $\longrightarrow$ N-Asetilserotonin $\longrightarrow$ Melatonin

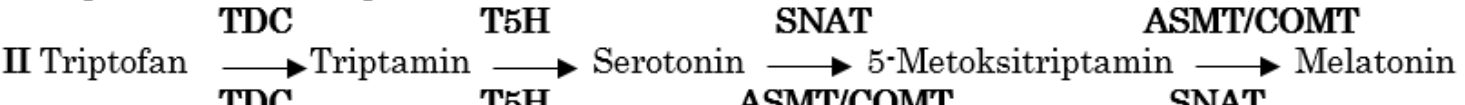

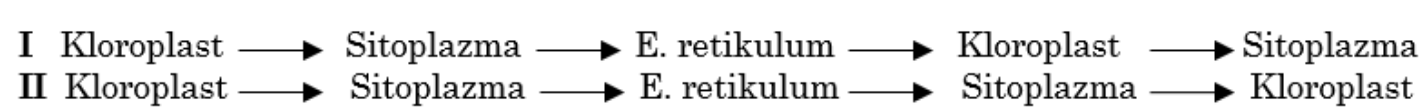

Şekil 2. Melatoninin biyosentez izyolları ve hücrede gerçekleşme yerleri (Back ve ark., 2016).

\section{Melatoninin Fizyolojik Görevleri}

Günlük ve ylllık ritim düzenleme ve fotoperyodik tepki

Hayvanlarda ve insanlarda melatonin, sadece gün içerisinde değil aynı zamanda yıl içerisindeki zamanın algilanmasında da önemli pay sahibidir. Memelilerde melatoninin daha çok geceleri sentezlendiği ve 1 şı altında kanda seviyesinin düştüğü bildirilmiştir (Cardinali ve Pevet, 1998). Bu nedenle kandaki miktar değişimleri, dokuların ve hücrelerin gün içerisindeki veya yıl içerisindeki zamanın algılamasına yardımcı olduğu ve dışarıdan yapılan melatonin 
uygulamalarının karanlık uygulamasını taklit ettiği için melatoninin hayvanlarda ve insanlarda fotoperyodik düzenleyici veya 24 saatlik ritmi (circadian rhytm, sirkadiyal ritim) düzenleyici olarak görev yaptığı bildirilmiştir (Reiter, 1991). Bitkilerde de hayvanlardakine benzer bir değişim olabileceği fikrinden hareketle 24 saatlik zaman dilimi içerisinde melatonin değişiminin ortaya konduğu ilk çalışmada, 12/12 saat karanlık/aydınlık $1 s ̧ ı$ rejimi altında yetiştirilen 15 günlük Chenopodium rubrum L. bitkilerinde melatonin seviyelerinin aydınlıkta çok düşük düzeyde seyrettiği buna karşılık karanlık periyodun sonlarına doğru ise en yüksek seviyeye ulaştığı bulunmuştur (Kolar ve ark., 1997). Bitkilerde de melatoninin 24 saatlik ritim düzenleyici olarak görev aldığı ve genel olarak sentez miktarının karanlıkta arttığı bildirilse de (Wolf ve ark., 2001), bazı araştırıcılar gün batımından hemen önce sentez miktarının en yüksek seviyeye ulaştığını bildirmiştir (Tan ve ark., 2007a). Bazı araştırıcılar ise, bitkilerde melatoninin daimi olarak bulunduğunu; fakat seviyesinin gün içerisinde değişiklik gösterdiği fikrini savunmaktadırlar (Paredes ve ark., 2009). Örneğin, arazi koşullarında yapılan bir çalışmada Malbec çeşidi üzüm danelerinin kabuklarında 24 saatlik zaman dilimi içerisinde melatonin seviyelerindeki değişim belirlenmiş ve en yüksek değer güneş doğarken tespit edilmiş ve daha sonraki saatlerde melatonin seviyesi düşüş göstermiştir (Boccolandro ve ark., 2011). Araştırıcılar bunun nedeninin melatonin seviyelerinin sirkadiyen ritim tarafindan kontrol edildiği ve aydınlık periyod döneminde melatonindeki azalmanın solar radyasyonun neden olduğu strese karşı antioksidan sistemin devreye girmesinden kaynaklanan aşırı melatonin tüketiminin olabileceğini bildirmişlerdir. Yine farklı meyve gelişim dönemlerindeki kirazlarda 24 saatlik zaman dilimi içerisinde meyvelerin melatonin içeriklerindeki değişimlerin incelendiği bir başka araştırmada, gün içerisindeki melatonin konsantrasyonunun iki kez pik yaptığg ve melatonin pikinin birincisinin karanlık periyodun sonunda (gün aydınlanmadan hemen önce), ikincisinin ise oksidatif stresin ve malondialdehit (MDA) içeriğinin arttığ ö ögleden sonra olduğu görülmüştür (Zhao ve ark., 2012). Araştırıcılar, öğleden sonra yüksek sıcaklık ve yüksek ışık yoğunluğunun etkisi ile MDA içeriğinin yüksek seviyelerde olmasinin melatonin sentezini tetiklediğini belirtmişlerdir. Bu durum, melatoninin birincil işlevinin oksidatif stres karşısında kiraz meyvesini korumak için antioksidan olarak görev yaptığını düşündürmektedir. Ayrıca, meyvelerin olgunlaşma aşamalarında melatonin içeriğindeki değişimler incelendiğinde, en yüksek seviyelerin 2 . evrede (tohumlar henüz sıvı formda ve endokarp henüz odunlaşmamış) olduğu görülmüştür. $\mathrm{Bu}$ aşamada meyve etinin gelişen tohumu korumada önemli bir rol sahibi olduğu ve tohum oluşumunun bu aşamasında oluşabilecek yüksek reaktif oksijen türleri (ROS) seviyelerine karşı melatoninin iyi bir ROS süpürücüsü olarak meyve gelişimi sırasında önemli bir rol oynadığı belirtilmiştir.

Su sümbülü ile yapılan bir çalışmada doğal koşullarda yetiştirilen bitkilerde gün içerisinde melatonin seviyesinin, hayvanlarda tespit edilen ritimden farklı olarak aydınlık zamanın sonlarına doğru bir artış gösterdiği gözlenmiş ve bunun da nedeninin fotosentez ve ışıtan korunma süreçleri ile ilişkili olabileceği belirtilmiştir (Tan ve ark., 2007a). Yeşil bir makro alg olan Ulva sp.'de 16 saat aydınlık/8 saat karanlık fotoperiyot altında en yüksek melatonin seviyesi gece 02:00'da tespit edilirken en düşük seviye ise 14:00'da bulunmuştur (Tal ve ark., 2011). Araştırıcılar, bunun gece boyunca sirkadiyen ritme bağlı enzim aktivitelerinin ve ışığa maruz kalmanın etkileri ile melatoninin ışı altında parçalanmasından kaynaklanabileceğini bildirmişlerdir. Elmada gün içerisinde melatonin değişiminin incelendiği bir diğer araştırmada, yapraklarda melatonin seviyesinin gün içerisinde iki kez (saat 14:30 ve 05:30'da) pik yaptığ 1 ve öğleden sonra belirlenen yüksek melatonin seviyesinin gün içerisinde yüksek sıcaklık stresi sonucu dokularda biriken yüksek MDA seviyesinin hemen ardından gerçekleştiği bulunmuştur (Zuo ve ark., 2014). Yine arpa ve acı baklada yapılan araştırmalarda kiraz ve elmadakilere benzer sonuçlar bulunmuş ve dokulardaki melatonin seviyesi gün içerisinde iki kez yüksek seviyeye ulaştığı görülmüştür (Arnao ve Hernandez-Ruiz, 2015a).

Gün içerisinde bitki dokularında melatoninin ve onun öncü maddesi olan Trp konsantrasyonlarının içeriğinin nasıl değiştiğini ortaya koymaya yönelik en kapsamlı çalışma patlıcan fidelerinde yapılmıştır (Korkmaz ve ark., 2017a). Yeni çimlenmiş (kotiledon aşamasında) fidelerde 24 saatlik zaman dilimi içerisinde melatonin içeriğinin biri karanlık periyodun başlamasından hemen sonra ve diğeri de aydınlık periyodun ortasında olmak üzere iki kez yükseldiği belirlenmiştir. Buna karşıllk melatonin ve Trp içerikleri arasında ters bir ilişki olduğu görülmüş ve melatonin seviyelerinin en yüksek olduğu zamanlarda Trp konsantrasyonunun en düşük değerlerde seyrettiği bulunmuş̧ur. Araştırmada dikim aşamasına gelmiş (4 yapraklı) fidelerin yapraklarında ve köklerinde yapılan ölçümlerde benzer sonuçlar elde edilmiş ve melatonin seviyelerinin gün içerisinde iki kez maksimuma ulaştığını fakat melatoninin en yüksek olduğu zamanlarda Trp içeriğinin en az seviyelerde seyrettiği belirlenmiştir. Buna karşılık, Arabidopsis thaliana bitkisinde yapılan bir diğer araştırmada ise, 12 saat karanlık ve 12 saat aydınlıkta yetiştirilen bitkilerde gün içerisinde melatonin seviyesinin önemli bir değişim göstermediği fakat suni ışık altında büyüyen Arabidopsis bitkilerine kıyasla doğal koşullar altında büyüyen bitkilerde melatonin 
içeriğinin daha yüksek olduğu görülmüştür (Hernandez ve ark., 2015). Tüm bu sonuçlar, bitkilerde gün içerisinde melatonin içeriğinin bitkinin biyolojik saatinin yanında içerisinde bulunduğu çevresel faktörlerin de kontrolü altında olduğu ve gün içerisinde analiz için örnek alımının yapıldığı zamanın bitki dokularındaki melatonin içeriğinin miktarı üzerinde önemli etkisi olduğunu göstermiştir. Ayrıca bitki dokularında gün içerisinde melatonin içeriğinin belirlenmesi ve çevresel faktörlerin etkisini daha iyi anlamak için farklı bitkiler üzerinde ilave çalışmaların yapılmasına ihtiyaç olduğu da bir gerçektir.

\section{Büyüme düzenleyici ve antioksidan olarak melatonin}

Bitkilerde melatoninin en temel rollerinden biri muhtemel bir bitki büyüme düzenleyicisi olarak görev almasıdır ve bu etkisi pek çok monokotil bitkide ortaya konmuştur. IAA ve melatonin arasındaki yapısal benzerlikler ve ortak biyosentez yolu, melatoninin bir oksin gibi hareket edebileceği fikrine yol açmıştır. Büyüme düzenleyici olarak melatoninin etkisinin araştırıldığı bir çalışmada, etiyole olmuş acı bakla (Lupinus albus L.) hipokotillerinde IAA'e benzer şekilde aktif büyümeyi uyarmakla birlikte yüksek konsantrasyonlarda ise engelleyici bir etki gösterdiği bildirilmiştir (Hernandez-Ruiz ve ark., 2004; Hernandez-Ruiz ve Arnao, 2008). Bitki içerisinde IAA'de olduğu gibi melatonin farklı dokularda farklı konsantrasyon dağılımlarına sahip olduğu ve ağırlıklı olarak apikal bölgelerin en yüksek melatonin içeriğine sahip olduğu bildirilmiştir (Murch ve Saxena, 2002; Sarropoulou ve ark., 2012). Araştırmalar, melatoninin etiyolleşmiş acı baklada IAA'e benzer rol oynadığını; yüksek konsantrasyonlarda engelleyici bir etkiye sahipken, mikromolar ve nanomolar seviyesindeki konsantrasyonlarda ise hipokotilin aktif büyümesini teşvik ettiğini göstermiştir. (Hernandez-Ruiz ve ark., 2004; Hernandez-Ruiz ve ark., 2005; Hernandez-Ruiz ve Arnao, 2008).

Melatoninin yine IAA'e benzer şekilde acı baklada adventif ve lateral köklerin oluşumunu arttırdığı görülmüş (Arnao ve Hernandez-Ruiz, 2007) ve bu önemli etkisi daha sonra kırmızı lahana, hıyar, kiraz, çeltik, Arabidopsis ve nar gibi diğer bitki türlerinde de gözlemlenmiştir (Posmyk ve ark., 2008; Park ve Back, 2012; Sarropoulou ve ark., 2012; Zhang ve ark., 2013; Sarrou ve ark., 2014; Zuo ve ark., 2014). Son zamanlarda Arabidopsis, soya fasulyesi, bermuda çimi (Cynodon dactylon) gibi pek çok türde dişarıdan yapılan melatonin uygulamalarının kök ve sürgün gelişmesini teşvik ettiği bulunmuştur (Bajwa ve ark., 2014; Shi ve Chan, 2014; Kostopoulou ve ark., 2015; Shi ve ark., 2015a; Wei ve ark., 2015). Bitkilerde adventif köklerin oluşumunda elde edilen verilere dayanılarak melatonin, bir bitki büyüme düzenleyici olarak kabul görmeye başlamıştır.
İnsanlarda ve hayvanlarda melatonin serbest radikalleri etkisiz hale getirmede aktif rol üstlenmesinden dolayı geniş spektrumlu antioksidan olarak kabul edilmesi, birçok araştırıcıda bu maddenin bitkilerde de benzer şekilde roller üstlendiği fikrinin doğmasına neden olmuştur. Antioksidan olarak melatoninin bitkiler üzerindeki görevi pek çok çalışmayla ortaya konmuştur (Paredes ve ark., 2009; Posmyk ve Janas, 2009; Park, 2011; Tan ve ark., 2012). Melatoninin biyolojik membranlarin (mitokondri, kloroplast ve plazma gibi) dengelenmesinde doğrudan antioksidan olarak rol oynadığı, zar akışkanlığı ve lipid peroksidasyonu ile mücadelede etkili olduğu belirtilmiştir (Catala, 2007; Garcia ve ark., 2014). Melatoninin stres altındaki bitkilerde $\mathrm{O}^{--}{ }_{2}$ oluşumunu sinırlayarak iç mitokondrial zardan elektron sızıntısını azalttığı, elektron taşıma zincirini uyardığı (Reiter ve ark., 2001). ve ayrica peroksidaz (POX), glutathion reduktaz (GR), superoksit dismutaz (SOD) ve katalaz (CAT) enzimlerinin aktivitelerini teşvik ettiği bildirilmiştir (Cardinali ve Pevet, 1998; Allegra ve ark., 2003; Teixeria ve ark., 2003; Rodriguez ve ark., 2004; Reiter ve ark., 2007). Aşırı soğuk, güneş ışığı, ağır metaller ve kimyasalların neden olduğu toprak kirliliği gibi olumsuz çevre koşullarında stres etmenleriyle başa çıkabilmek için bitkilerde melatonin üretiminin teşvik edildiği bulunmuştur (Arnao ve Hernandez-Ruiz, 2009a; Tal ve ark., 2011; Arnao ve Hernendez-Ruiz, 2013a; Byeon ve Back, 2014). Ayrıca, zehirli kimyasal ve çevresel kirleticilerle baş edebilen su sümbülünde melatonin ve onun bir metaboliti olan AFMK (N1-acetyl-N2-formyl-5-methoxykynuramine) seviyelerinin yüksek olması, melatoninin güçlü bir serbest radikal süpürücü olarak bitkilerin, toprak ve su kirleticilerin neden olduğu ağır hasarlar ile baş edebilmelerinde ve dolayısıyla fiteromediasyonda kullanılabileceği bildirilmiştir (Tan ve ark., 2007a).

Melatonin uygulamaları sonrasında çeşitli abiyotik streslere maruz kalan bitkilerde ROS miktarında azalma ve aminoasit, organik asit ve şeker içeriklerinde ise artışlar olduğu görülmüştür (Shi ve ark., 2015a). Örneğin, biber tohumlarına ekim öncesi yapilan melatonin uygulamaları sonucunda tohumların üşüme stresi $\left(15{ }^{\circ} \mathrm{C}\right)$ koşulları altında çimlenme ve çıkış performanslarının arttığı ve bu artışın antioksidan enzimlerin aktivitelerinin teşvik edilmesinden kaynaklandığı bildirilmiştir (Korkmaz ve ark. 2017b). Domates fidelerinin yapraklarına yapılan melatonin uygulaması sonucunda şeker, prolin ve antioksidan enzim aktivitesinin yükseldiği ayrıca soğuk stresi altında aktif hale geçen birçok genin ifade edilme seviyelerinin önemli ölçüde yükseldiği bildirilmiştir (Ding ve ark., 2017). Benzer şekilde soya fasulyesi tohumlarına yapılan melatonin uygulamalarının fidelerin tuz stresine karşı toleranslarını arttırdığı ortaya konmuştur (Wei ve ark., 2015). Araştırıcılar, tuz stresinin bitki dokularında birçok genin ifade edilme seviyesini 
düşürdüğünü ama melatonin uygulamalarının başta hücre bölünmesi, fotosentez, yağ asitleri sentezi ile askorbat ve karbonhidrat metabolizmalarında görev alan çok sayıda genin ifade seviyesinin yükselttiğini ve bunların strese maruz kalan bitkilerde verimi önemli seviyede arttırdığını bildirmişlerdir. Tüm bu araştırmalar, melatoninin antioksidan olarak özellikle savunma sistemini teşvik ettiğini ve bunu da stres altında görev yapan ya da aktif hale gelen bazı genlerin ekspresyonlarını teşvik ederek gerçekleştiğini ortaya koymuştur.

\section{Stres koşullarındaki bitkilerde içsel melatonin seviyesinde görülen değişimler}

Hem biyotik hem de abiyotik stres faktörlerinin bitkilerde melatonin sentezini teşvik ettiği fikri bitkilerde melatoninin var olduğunun belirlenmesiyle ortaya atılmıştır. Örneğin, bitkilerde melatoninin varlığını ilk ortaya koyan araştırmacı grubu olan Dubbels ve ark. (1995) yabani domatesin ( $L$. pimpinellifolium) kültür domateslerine ( $L$. lycopersicum) kıyasla 5 kat daha az melatonin içerdiğini ve bunun da sonucu olarak kültür domates çeşitlerinin yüksek ozon seviyelerine karşı daha tolerant olduğunu bildirmişlerdir. Aynı araştırıcılar yüksek ozona karşı toleranslı olan tütün varyetelerin hepsinde melatonin içeriğinin yüksek olduğunu ve yüksek melatonin konsantrasyonlarının ozon zararı nedeniyle üretilen serbest radikallerin etkisiz hale getirilmesinde etkin olarak görev aldığını bildirmişlerdir. Yine Alp'lerde ve Akdeniz’in yüksek kesimlerinde yüksek UV radyasyonu altında yaşayan bitkilerin, aynı türlerin daha düşük rakımlarda ve düşük UV radyasyonu altında yaşayan ekotiplerine kıyasla çok daha fazla melatonin içerdiği bildirilmiştir (Tettamanti ve ark., 2000). Ayrıca, düşük sıcaklık, yüksek sicaklık ve toprak kirliliği gibi olumsuz çevre koşulları altında yaşayan bitkilerde melatonin içeriğinin normale göre daha fazla olduğu da değişik araştırıcılar tarafından belirtilmiştir (Tan ve ark., 2007 a ve $2007 b)$.

Stres faktörlerine maruz kalan bitkilerde görülen melatonin seviyesindeki geçici artışlar, özellikle oksidatif stresin neden olduğu zararlı etkilere karşı bitkileri korumaya yönelik olduğu bildirilmiştir. Örneğin, tuz, çinko, düşük sıcaklık ve kuraklık gibi değişik stres faktörleri altındaki arpa ve acı bakla bitkilerinde içsel melatonin seviyelerinin stres faktörünün şiddetine ve uygulama zamanına göre ciddi artışlar gösterdiği bildirilmiştir (Arnao ve Hernandez-Ruiz, 2009b ve 2013a). Araştırıcılar, çinko stresi altındaki arpa bitkilerinde 6, acı bakla bitkilerinde 12 kat; soğuk stresi $\left(6{ }^{\circ} \mathrm{C}\right)$ altındaki acı bakla bitkilerinde kontrol bitkilerine kıyasla $\left(24{ }^{\circ} \mathrm{C}\right)$ 2,5 kat ve su stresi altındaki acı bakla bitkilerinde ise 4 kata varan içsel melatonin seviyelerinde artışlar olduğunu belirtmişlerdir. Tarla koşullarında yetiştirilen domateslerin yapraklarında, iklim odasında (kontrollü koşullarda) yetiştirilen domateslere kıyasla melatonin seviyesi 10 kat daha fazla olarak bulunmuştur (Arnao ve Hernandez-Ruiz, 2013b). Benzer sekilde, tuz stresine maruz kalan ayçiçeği fidelerinin köklerinde 2 kat, kotelidonlarında ise 6 kat daha fazla melatonin olduğu ve bu artışın melatonin sentezinde rol alan son enzim olan HIOMT sentezinin teşvik edilmesinden kaynaklandığı belirlenmiştir (Mukherjee ve ark., 2014). Araştırıcılar, kontrol bitkilerine kıyasla tuz stresi altındaki bitkilerde bu enzim aktivitesinde \%72 artış olduğunu belirlemişlerdir. Herbisit ve kadmiyum kaynaklı oksidatif stres koşulları altındaki çeltik fidelerinde melatonin sentezinde görev alan 3 enzimin (T5H, TDC ve HIOMT) seviyelerinde önemli artışlar görülmüş ve bunun da içsel melatonin seviyelerinde 6 kata varan artışlara neden olduğu bildirilmiştir (Park ve ark., 2013; Byeon ve ark., 2015). Yine, $37{ }^{\circ}$ C'de yüksek sıcaklık stresine maruz kalan Arabidobsis fidelerinin içsel melatonin içeriğinin kontrol bitkilerine kıyasla 2 ile 5 kat daha yüksek olduğunu bulunmuştur (Shi ve ark., 2015b). Tüm bu sonuçlar, stres altında yetişen veya hayatlarının belli dönemlerinde herhangi bir stres faktörüne maruz kalan bitkilerde içsel melatonin seviyelerinde kayda değer oranlarda artışlar olduğu ve bu artışların da strese karşı savunma mekanizmalarını harekete geçirmek amaçlı olduğu görülmüştür.

Melatoninin bir biosit olarak başta bazı mantar ve bakteriler olmak üzere çeşitli biyotik stres faktörlerine karşı tolerans sağladığı bildirilmiş fakat bu alanda elde edilen sonuçlar abiyotik stres faktörleri ile kıyaslandığında henüz emekleme aşamasındadır. Bu alanda ilk bilgiler elmalarda Marssonina lekesi olarak bilinen yaprak hastalığına neden olan bir fungal etmen olan Diplocarpon mali ile yapilan bir çalışmadan gelmiştir (Yin ve ark., 2013). Araştırıcılar, melatonin ile takviye edilmiş suyla sulanan elma ağaçlarında hastalık etmeninin daha az yaprak dökülmesine neden olduğunu ve bunu da artan fenilalenin liyaz aktivitesi ile başta kitinaz (chitinase) ve $B-1,3$ glucanase olmak üzere çeşitli patojenite ile ilgili proteinlerin sentezlenmesinin teşvik edildiğinden kaynaklandığını bildirmişlerdir. Biyotik stres faktörleri ve melatonin arasındaki ilişkiyi ortaya koyan en ilgi çeken çalışma Lee ve ark. (2015) tarafından yürütülmüştür. Genetik modifikasyon yoluyla SNAT enziminin çalışmasının engellenmesi nedeniyle çok düşük melatonin üretebilen Arabidopsis bitkilerinde Pseudomonas syringae pv. Tomato DC3000 isimli patojene karşı hassasiyetin ciddi seviyelerde yükseldiği; bunun da nedeninin düşük melatonin seviyesinin salisilik asit üretiminde ciddi düşüşlere neden olduğu gösterilmiştir.

Melatonin kullanımının yaşlanma üzerine etkisi Hayvanlarda melatoninin, yaşlanmayla ilgili bozuklukları engellediği ve genetik koşullara bağlı 
olarak bazı memelilerin yaşam ömrünü bir dereceye kadar uzattığı bilinmektedir (Hardeland ve Poeggeler, 2012). Bitkilerde yaşlanma süreci ile ilgili yapılan çalışmalarda araştırıcılar organizmanın hayatından ziyade yapraklarda meydana gelen yaşlanma etkisine odaklandıkları için hayvanlarda görülen yaşlan madan daha farklı bir süreç yaşanmaktadır. Bununla birlikte her ikisinde de görülen ortak nokta, yaşlanma ilerledikçe ilgili hücrede oksidatif zararlanma sonucu oluşan hasarın artmasıdır. Her iki durumda da melatoninin antioksidan özelliği yaşlanmanın geciktirilmesine katkıda bulunduğu da bilinen bir gerçektir (Hardeland, 2013).

Bitkilerin yaşlanmasında melatoninin sahip olduğu rol tam olarak ortaya konmuş değildir. Diğer yandan melatoninle muamele edilmiş Arabidopsis fidelerinin transkriptomik analizinde etilen, absisik asit, jasmonik asit ve salisilik asit gibi yaşlanmayı teşvik edici veya bu fitohormanları harekete geçiren sinyallerin oluşmasında rol alan sayısız genin düzenlendiği ifade edilmiştir (Jibran ve ark., 2013; Khan ve ark., 2014). Bu durum ilk bakışta melatoninin bitkilerde yaşlanmayı teşvik edici bir rol aldığını gösterebilir. Çeltikte yaprak yaşlanması sürecinde gözlenen Trp, serotonin, $\mathrm{N}$-asetilseratonin ve melatoninin miktarında meydana gelen önemli artışlar bu duruma uygun görünmektedir. Ancak bununla birlikte melatoninin strese cevap veren, koruyan ve yaraların iyileşmesini sağlayan fitohormanları da harekete geçirdiğini göz ardı etmemek gerekmektedir.

Melatonin sentezinde anahtar enzimlerden biri olan AANAT'ı aşırı miktarda üreten 7 günlük transgenik çeltik fidelerinde yapılan bir çalışmada, yaşlanmada görev alan protein 29 (SAG29) ile poligalakturonaz enzimini kodlayan genlerin aktivitelerinin azaldığ ortaya konmuştur (Byeon ve ark., 2013). Daha önceki çalışmalar incelendiğinde, melatoninin arpanın yapraklarında klorofil bozulmalarına karşı koruyucu bir etkiye sahip olduğu görülmüştür (Arnao ve Hernández-Ruiz, 2009a). Benzer şekilde kopmuş elma yapraklarında dışarıdan yapılan melatonin uygulaması sonucunda başta klorofil parçalanmasına neden olan enzimlerin üretilmesini kontrol eden genler olmak üzere yaşlanma ile ilgili birçok spesifik genin aktivitelerinin azaldığ bildirilmiştir (Wang ve ark., 2013, 2014). Araştırıcılar dokulardaki ROS birikiminin yaşlanmanın ana nedeni olduğunu, melatoninin de başta $\mathrm{H}_{2} \mathrm{O}_{2}$ olmak üzere çeşitli ROS miktarlarında kayda değer düşüşlere neden olarak yaşlanmayı geciktirdiğini ve tüm bunların da melatoninin antioksidan doğasından kaynaklandığını belirtmişlerdir.

Son yıllarda yapılan çalışmalar, melatoninin değerli genetik materyalin sıvı azot içerisinde çok uzun sürelerde saklanmasında önemli rol üstlendiğini ve tohumların depolanmasında yaşlanmayı geciktirdiğini ortaya koymuştur. Depolama öncesi yapılan melatonin uygulamaları ile Rhodiola crenulata kalluslarının (Zhao ve ark., 2011) ve dormant Amerikan karaağaç tomurcuklarının (Uchendu ve ark., 2013) sıvı azot içerisinde başarı ile depolanabileceği ortaya konmuştur. Her iki araştırmada da melatoninin bitkisel materyalin sıvı azot içerisinde saklanabilmesinde bir antioksidan olarak görev yaparak CAT ve POD gibi antioksidan enzimlerinin aktivitelerini teşvik ettiği ve dokulardaki MDA birikimini azalttığ̆ ortaya konmuştur.

Melatoninin tohum yaşlanmasındaki etkilerini ortaya koyan ilk bulgular Kołodziejczyk ve ark. (2015) tarafından üretilmiştir. Araştırıcılar, mısır ve hıyar tohumlarının bir yıl süreyle depolanması sırasında tohum içerisinde melatonin değişimini izlemişlerdir. Her iki bitkinin tohumunda da depolama başlangıcında düşük düzeylerde seyreden melatonin seviyesinin, depolamanin 4 ve 5 . aylarında (Ocak ve Şubat aylarında) hızla yükseldiğini ve kış aylarında görülen melatonin seviyelerindeki bu artışların tohumları olumsuz çevre koşullarına karşı korumak için bir savunma mekanizması olarak gerçekleştiği bildirilmiştir. Tohum yaşlanması üzerine melatoninin etkilerini ortaya koymak üzere yapılan bir diğer çalışmada melatonin ile muamele edilmiş biber tohumları 1 yıl süreyle depolanmıştır (Köklü, 2016). Depolama öncesi tohumlara uygulanan melatoninin, tohumlarda bozulmanın bir göstergesi olan elektriksel iletkenlik seviyesini, hiç melatonin uygulanmamış tohumlara kıyasla önemli derecelerde azalttığı; bununla birlikte antioksidan enzim aktivitelerini olumlu yönde arttırdığı görülmüştür. Bir yıl süren depolama sırasında tohumların içsel melatonin seviyelerinde mevsimsel olarak bir değişimin olduğu ve melatonin seviyesinin depolamanın 8 . ayına denk gelen kış aylarında ciddi derecede yükseldiği ortaya konmuştur.

\section{Bitkilerde Melatonin Alımı}

Melatonin içeren bitkiler bu indolamini sentezleyebilirler; ayrıca dışarıdan yetiştirme ortamına yani toprağa ya da bitkinin kendisine (yaprağa) uygulanan melatonini almaları da mümkündür (Reiter ve ark. 2001). Vişnede (Prunus cerasus L.) melatonin varlığı ile ilgili yapılan bir çalışmada melatoninin vişne meyvesinde sentezlenmesinin yanında meyveye kökler aracılığı ile de taşınabileceği bildirilmiştir (Burkhardt ve ark., 2001). Su sümbülünde [Eichhornia crassipes (Mart) Solms] yapılan bir araştırmada dışarıdan $5 \mu \mathrm{M}$ melatonin uygulamasinın yapraklardaki melatonin seviyelerini uygulanmayanlara göre daha fazla arttırdığı bildirilmiştir. Bazı çalışmalar da melatoninin sadece köklerden alınmadığını, aynı zamanda tohumların ve yaprakların da absorbe (alım) yeteneğine sahip olduğunu göstermiştir. Örneğin, değişik konsantrasyonlarda melatonin uygulanmış arpa yapraklarında konsantrasyona bağlı olarak 
melatonin miktarının arttığı belirlenmiştir (Arnao ve Hernandez-Ruiz, 2008). Yine tohuma yapılan melatonin uygulamaları ile ilgili çalışmalarda tohumun bünyesine melatonini aldığı görülmüştür. Değişik konsantrasyonlarda melatonin uygulanmış biber tohumlarında melatonin uygulaması sonucu tohumların düşük sicaklıkta çimlenme performansının olumlu etkilendiği ve elde edilen fidelerde konsantrasyonlara bağll olarak melatonin içeriklerinde önemli artışlar olduğu belirlenmiştir (Korkmaz ve ark. 2017b). Benzer şekilde oda koşullarında yapılan depolama öncesi 50 ve $500 \mu \mathrm{M}$ konsantrasyonlarında melatonin uygulanmış hıyar ve misir tohumlarinda bir yil boyunca melatonin içeriğinin sezonsal değişiminin izlendiği bir çalışmada her iki türde de yıl sonunda melatonin uygulanmış tohumlarda uygulanmamış olanlara kıyasla melatonin içerikleri daha yüksek bulunmuş ve yaşlanmanın yavaşladığı ortaya konmuştur (Kołodziejczyk ve ark., 2015).

\section{Bitkilere Dışarıdan Melatonin Uygulaması ve Bitki Gelişimine Etkisi}

Olumsuz çevre koşulları altında yaşayan ve bu koşullara karşı toleranslı olan bitkilerde bulunan yüksek melatonin içeriği gerçeği, son yıllarda bu maddenin bitkilere dışarıdan uygulanması yoluyla stres koşullarına karşı tolerans kazanmaları yönündeki araştırmaları tetiklemiştir. Dışarıdan yapılan melatonin uygulamaları tohum uygulaması olarak, yapraklara sprey olarak ya da sulama suyu vasitasıyla köklere olmak üzere farklı yöntemlerle yapılabilmektedir. Örneğin, dışarıdan tohuma yapılan melatonin uygulamalarının hiyar (Posmyk ve ark., 2009) ve biber (Korkmaz ve ark., 2017b) tohumlarının düşük sıcaklıkta $\left(15^{\circ} \mathrm{C}\right)$ çimlenme performanslarını olumlu yönde etkilediği ve bu artışın nedeni olarak da melatoninin tohumlarda hücre zarlarında bulunan yağ asidi bileşiklerini peroksidasyona karşı koruması olarak gösterilmiştir. Yine, ekim öncesi 1-100 $\mu \mathrm{M}$ aralığındaki melatonin konsantrasyonlarında yapılan tohum uygulamalarının kırmızı lahana tohumlarının ağır metal (bakır) stresi altında çimlenme performansları üzerine etkilerinin araştırıldığı bir araştırmada, 1 ve $10 \mu \mathrm{M}$ melatonin konsantrasyonlarının çimlenmeyi kontrole göre \%20 arttırdığı buna karşılık bu uygulamaların lipid peroksidasyonunu da kayda değer oranda azalttığı bulunmuştur (Posmyk ve ark., 2008).

$\mathrm{Li}$ ve ark. (2012), köklere yapılan $0.1 \mu \mathrm{M}$ melatonin uygulamasının tuz stresi altında yetiştirilen Malus hupehensis bitkisinde başta POX olmak üzere antioksidan enzimlerin aktivitelerinde artışlara neden olduğu ve bunun da membranlardaki hasarın azalmasına ve dolayısıyla da tuza karşı toleransın artmasında etkili olduğunu bildirmişlerdir. Benzer şekilde Xu ve ark. (2010), yüksek sıcaklık stresi altında yetiştirilen hıyar fidelerine dışarıdan yaptığı melatonin uygulamaları sonrasında bitki dokularında biriken serbest radikallerin miktarında ve doku elektrik iletkenliğinde önemli düşüşler olduğunu buna karşılık SOD, CAT ve POX gibi enzimatik ve askorbat ve glutathion gibi enzimatik olmayan antioksidanların aktivitelerinde önemli yükselişler olduğunu belirtmiştir. Son olarak Arabidobsis fidelerine dışarıdan yapılan $20 \mu \mathrm{M}$ melatonin uygulamasının yüksek sicaklık stresi $\left(45{ }^{\circ} \mathrm{C}, 2\right.$ saat) sonrasinda hayatta kalma oranının \%50'ye yükseldiğini (kontrol bitkilerinde \%5) ve heat-shock protein sentezini kontrol eden HSFs tipi genleri uyardiğg bildirilmiştir (Shi ve ark., 2015b).

Melatoninin bitkilerde fotosentetik süreç üzerine etkilerine de ayrıca değinmek gerekmektedir. Bir yaşındaki elma fidanlarına dışarıdan yapılan melatonin uygulamasının kuraklık stresi koşulları altında senesensi (yaprak yaşlanmasını) ve bunun yanında yapraklardaki klorofil parçalanmasını önemli oranda önlediği bulunmuştur (Wang ve ark., 2013). Araştırmacılar, senesensde görev alan 12 tane genin melatonin uygulaması ile ifade edilme seviyelerinin baskılandığını ortaya koymuşlar ve melatonin uygulaması sonrasinda kuraklık stresi altındaki elma fidanlarında fotosentez hızının iyileştiğini bunun da fotosistem II'de meydana gelen iyileşmelerden kaynaklandığını belirtmişlerdir. Yakupoğlu (2016) üşüme stresi öncesi dışarıdan (topraktan) melatonin uygulanmış patlıcan fidelerinde yaprak alanı, gövde ve kök yaş ve kuru ağırlıkları, bitki-su ilişkileri ile fotosentez hızı ve stoma iletkenliği gibi fotosentetik parametreler açısından melatonin uygulamalarının daha iyi sonuç verdiğini bildirmiştir. Ayrıca Li ve ark. (2015) dışarıdan uygulanan melatoninin kuraklık stresi altındaki Malus hupehensis bitkilerinde stomaların daha uzun süre ve daha geniş bir şekilde açık kalmasını sağladığı dolayısıyla da fotosentez hızını ve stoma iletkenliğini arttırdığını fakat ABA miktarını yarı yarıya azalttığını ve bunun da nedeninin ABA sentezinde görev alan anahtar bir enzimin sentezinin engellenmesi olduğunu belirtmişlerdir. Son olarak yapraklarına melatonin uygulanmış ve soğuk stresine maruz kalmış domateslerde fotosentez hızının kontrol bitkilerine kıyasla yüksek olduğu ve bunun da nedeninin Calvin döngüsünde görev alan anahtar bir enzim olan sedoheptulose-1,7-bisphosphatase (SBPase), üretiminden sorumlu olan SlSBP geninin teşvik edilmesinden kaynaklandığı bildirilmiştir (Ding ve ark., 2017).

Son yıllarda az sayıda yapılan birkaç araştırmada dışarıdan yapılan melatonin uygulamalarının bitkilerde verim ve kalite üzerine olumlu etkilerinin olduğu bildirilmiştir. Örneğin tohuma yapılan $50 \mu \mathrm{M}$ melatonin uygulamasinın misır, hıyar ve maş fasulyesinde toplam verimde önemli artışlar sağladığı, mısırda koçan sayısı ve koçan büyüklüğunün arttığı, maş fasulyesinde bitki başına bakla sayısının arttığı, 
hıyarda ise bitki başına daha fazla meyve alındığ bildirilmiştir (Janas ve Posmyk, 2013). Benzer şekilde Yakupoğlu (2016) çiçeklenme aşamasında patlıcan bitkilerine yapılan $5 \mu \mathrm{M}$ konsantrasyonundaki melatonin uygulamasinin ilkbaharda isitmasız seralarda yetiştirilen ve üşüme stresine maruz kalan patlicanlarda toplam verimde \%30, erkenci verimde ise iki kata varan artışlar sağladığını belirtmiştir. Son olarak Sun ve ark. (2015) hasat edilmiş domates meyvelerinin 2 saat süreyle $50 \mu \mathrm{M}$ melatonin ile muamele edilmesi sonrasında likopen miktarında 5.8 kat, renk oluşumunu kontrol eden genlerin ifade seviyelerinde ise 2 kat artışlar olduğunu; melatonin uygulamasının etilen üretimini tetiklediği ve meyve eti yumuşamasını arttırdığını bildirmişlerdir. $\mathrm{Bu}$ sonuçlar ışığında her ne kadar melatoninin bitkilerde verim ve kaliteyi arttırıcı etkilerinin olduğu görülse de bu sonuçların daha farklı bitki türlerini de içeren yapılacak olan yeni çalışmalarla desteklenmesine ihtiyaç olduğu da bir gerçektir.

\section{Genetik Modifikasyon Yoluyla Melatonin İçeriği Yüksek Genotiplerin Eldesi}

Bitki biyoteknolojisinin temel amaçlarından biri de strese toleransı yüksek ve/veya besin içeriği zenginleştirilmiş ürünler elde etmektir. İnsanlarda günlük ritmi ve uykuyu düzenlemek, antioksidan ve antikanserojen özelliklerinden faydalanmak amacıyla yurtdışında melatonin reçetesiz olarak marketlerin eczane bölümlerinde satılmakta ve geniş kitleler tarafindan tüketilmektedir. İnsanlarda günlük 1 ile $300 \mathrm{mg}$ melatonin tüketmenin önerildiği, hatta 30 gün boyunca $1 \mathrm{~g}$ melatonin tüketmenin herhangi bir yan etkiye neden olmadığı belirtilmiştir (BonnefontRousselot ve Collin, 2010). Melatoninin ticari preparatlar olarak tüketilmesinden ziyade melatonin içeriği yüksek bitkisel besinlerin tüketilmesi gerektiği ve bu nedenle de melatonin içeriği yüksek ürünlerin ıslah edilmesinin gerekliliği son zamanlarda yapılan çalışmalarda sıkça dile getirilmektedir (FernandezMar ve ark., 2012; Garrido ve ark., 2010; Arnao ve Hernandez-Ruiz, 2015b). Örneğin doku kültüründe kimyasal mutagen uygulamaları sonucu seçilen bir sarı kantaron (Hypericum perforatum L.) hattının diğer genotiplerle kıyaslandığında 12 kat daha fazla melatonin içerdiği ve bu hattın insanlarda birçok hastalığın tedavisinde zengin bir melatonin ya da antioksidan kaynağı olarak kullanılabileceği bildirilmiştir (Murch ve Saxena, 2006). Ayrıca, genetik modifikasyon sonucu bazı bitki türlerinde yüksek miktarlarda içsel melatonin üretebilen hatların elde edilebileceği ve bu bitkilerin de çeşitli stres faktörlerine karşı tolerans göstermede çok daha başarılı oldukları son yıllarda yapılan çalışmalarla ortaya konmuştur. Örneğin Okazaki ve ark. (2009) melatonin sentezinde görev alan son enzim olan AANAT enzimini aşırı üreten transgenik domates bitkilerinin yapraklarinda konsantrasyonunun, transgenik olmayan bitkilere kıyasla 7 kat daha fazla olduğu halde bitkilerde herhangi bir fenotipik farklılığın gözlemlenmediği bildirilmişlerdir. Yine Kang ve ark. (2010) yüksek miktarlarda SNAT enzimi üretebilen transgenik çeltik hatlarının 8 kat daha fazla melatonin içerdiği ve 12 ${ }^{\circ}$ 'de 8 gün süren soğuk stresi sonrasında transgenik hatların kontrol bitkilerine kıyasla yaklaşık 2.5 kat daha fazla klorofile sahip olduğunu ve bunun da soğuk stresine karşı toleransı arttırdığını bildirmişlerdir. Son olarak Park ve ark. (2013) genetik modifikasyon sonucu yüksek miktarlarda TDC enzimi üretebilen çeltik bitkilerinin herbisit stresi sonrası kontrol bitkilerine kıyasla yaklaşık 20 kat daha fazla melatonin ürettiğini, antioksidan enzimlerin aktivitelerinin teşvik edildiğini buna karşılık dokularda üretilen serbest radikal miktarında ciddi düşüşler olduğunu bildirmişlerdir.

\section{SONUC ve ÖNERILER}

$\mathrm{Bu}$ derlemede bitkilerde varlığının keşfinden itibaren üzerinde her geçen gün artan sayıda araştırma yapılmakta olan ve son yıllarda bir bitkisel büyüme düzenleyici olarak kabul edilen melatoninin bitkilerde varlığı ve üstlendiği görevler hakkında okuyucuya detaylı bilgi verilmeye çalışılmıştır. Mevcut veriler ve gözlemlere dayanarak, tarımsal üretimde melatoninin yadsinamaz bir öneminin olduğu görülmektedir. Bunun nedenleri şu şekilde özetlenebilir: (i) bir antioksidan olarak melatoninin yüksek sıcaklık, düşük sıcaklık, kimyasal kirleticiler ve diğer çevresel saldırılara karşı bitkilerin toleransını artırması; (ii) melatoninin oksidatif strese karşı klorofili koruması ve bitkilerdeki fotosentez oranını hızlandırması ve (iii) melatoninin kök sisteminin gelişmesini uyarması ile kök yenilenmesini desteklemesi. Son yıllarda yapılan çalışmalarla biyoteknolojik ve moleküler yöntemler yardımıyla bitkilerde içsel melatonin seviyesinin arttırılmasının mümkün olduğu ortaya konmuştur. O nedenle bu alanda elde edilecek olan bir başarı, hem bitkilerin stres şartlarına karşı koyma başarısını arttıracak, hem de insanların melatonin içeriği yüksek

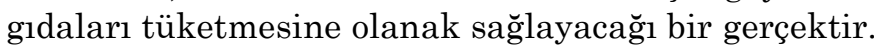
Tüm bu nedenlerden dolayı bu molekülün bitkilerde üstlendiği görevlerin daha iyi anlaşılması için çok fazla sayıda yeni araştırmanın yapılması gerekmektedir.

\section{TEŞEKKÜR}

Bu derleme, TÜBİTAK (Proje no: 115 O 020) ve KSÜ BAP Birimi (Proje no: 2013/1-23M) tarafindan desteklenen projelerden üretilmiştir. Her iki kuruma da mali destek için teşekkür ederiz.

\section{KAYNAKLAR}

Allegra M, Reiter RJ, Tan DX, Gentile C, Tesoriere L, Livrea MA 2003. The Chemistry of Melatonin's Interaction with Reactive Species. Journal of Pineal Research, 34 (1): 1-10. 
Anonim 2015. htp://www.sigmaaldrich.com/catalog /product/sigma/m5250?lang=en\&region=TR (erişim tarihi: 15.10.2015)

Arnao MB 2014. Phytomelatonin: Discovery, Content, and Role in Plants. Advances in Botany, Article ID 815769, 11.

Arnao MB, Hernández-Ruiz J 2008. Assessment of Different Sample Processing Procedures Applied to the Determination of Melatonin in Plants. Phytochemical Analysis, 20 (1): 14-18.

Arnao MB, Hernandez-Ruiz J 2009a. Chemical Stress by Different Agents Affects the Melatonin Content of Barley Roots. Journal of Pineal Research, 46: 295-299.

Arnao MB, Hernandez-Ruiz J 2009b. Protective Effect of melatonin Against Chlorophyll Degradation During the Senescence of Barley Leaves. Journal of Pineal Research, 46 (1):58-63.

Arnao MB, Hernandez-Ruiz J 2013a. Growth Conditions Determine Different Melatonin Levels in Lupinus albus L. Journal of Pineal Research, 55: 149-155. 136.

Arnao MB, Hernandez-Ruiz J 2013b. Growth Conditions Influence The Melatonin Content of Tomato Plants. Food Chemistry, 138 (2-3): 1212-1214.

Arnao MB, Hernandez-Ruiz J 2015a. Functions of Melatonin in Plants: A Review. Journal of Pineal Research, 59: 133-150.

Arnao MB, Hernandez-Ruiz J 2015b. Phytomelatonin: Searching for Plants with High Levels for Use As Natural Nutraceutical. Studies in Natural Products Chemistry, 46: 523-549.

Arnao MB, Hernandez-Ruiz J, 2007. Melatonin Promotes Adventitious and Lateral Root Regeneration in Etiolated Hypocotyls of Lupinus albus L. Journal of Pineal Research, 42: 147-152.

Back K, Tan D-X, Reiter R J 2016. Melatonin Biosynthesis in Plants: Multiple Pathways Catalyze Tryptophan to Melatonin in the Cytoplasm or Chloroplasts. Journal of Pineal Research, 61: 426-437.

Bajwa VS, Shukla MR, Sherif SM, Murch SJ, Saxena PK 2014. Role of Melatonin in Alleviating Cold Stress in Arabidopsis thaliana. Journal of Pineal Research, 56: 238-245.

Boccalandro HE, Gonzalez CV, Wunderlin DA, Silva MF 2011. Melatonin Levels, Determined by LC-ESIMS/MS, Fluctuate during the Day/Night Cycle in Vitis vinifera cv Malbec: Evidence of Its Antioxidant Role in Fruits. Journal of Pineal Research, 51: 226-232.

Bonnefont-Rousselot D, Collin F 2010. Melatonin: Action as Antioxidant and Potential Applications in Human Disease and Aging. Toxicology, 278: 55-67.

Burkhardt S, Tan DX, Manchester LC, Hardeland R, Reiter RJ 2001. Detection and Quantication of the Antioxidant Melatonin in Montmorency and Balaton Tart Cherries (Prunus cerasus). Journal of Agriculture and Food Chemistry, 49: 4898-4902.

Byeon Y, Lee HY, Lee K, Park S, Back KW 2014. Cellular localization and kinetics of the Rice Melatonin
Biosynthetic Enzymes SNAT and ASMT. Journal of Pineal Research, 56: 107-114.

Byeon Y, Tan DX, Reiter RJ, Back K 2015. Predominance of 2-Hydroxymelatonin over Melatonin in Plants. Journal of Pineal Research, 59 (4): 448-454.

Byeon, Y, Back, K 2014. Melatonin Synthesis in Rice Seedlings In-vivo is Enhanced at High Temperatures and under Dark Conditions due to Increased Serotonin $\mathrm{N}$-acetyltransferase and N-acetylserotonin Methyltransferase Activities. Journal of Pineal Research, 56: 189-195.

Byeon, Y, Park, S, Kim, YS, Back, KW 2013. Microarray Analysis of Genes Differently Expressed in MelatoninRich Transgenic Rice Expressing a Sheep Serotonin NAcetyltransferase. Journal of Pineal Research, 55: 357363.

Cardinali DP, Pevet P 1998. Basic Aspects of Melatonin Action. Sleep Medicine Reviews, 2: 175-190.

Catala A 2007. The Ability of Melatonin to Counteract Lipid Peroxidation in Biological Membranes. Current Molecular Medicine, 7(7): 638-49.

Chen G, Huo Y, Tan DX, Liang Z, Zhang W, Zhang Y 2003. Melatonin in Chinese Medicinal Herbs. Life Sciences, 73: 19-26.

De La Puerta C, Carrascosa-Salmoral MP, Garcia-Luna PP, Lardone PJ, Herrera JL, Fernandez-Montesinos R 2007. Melatonin is a Phytochemical in Olive Oil. Food Chemistry, 104: 609-612.

De luca V, Marineau C, Brisson N 1989. Molecular Cloning and Analysis of cDNA Encoding A Plant Tryptophan Decarboxylase Comparison with Animal Dopa Decarboxylases. Proceedings of the National Academy of Sciences, 86: 2582-2586.

Ding F, Liu B, Zhang S 2017. Exogenous Melatonin Ameliorates Cold Induced Damage in Tomato Plants. Scientia Horticulturae, 219: 264-271

Dubbels R, Reiter RJ, Klenke E, Goebel A, Schnakenberg E, Ehlers C 1995. Melatonin in Edible Plants Identified by Radioimmunoassay and by High Performance Liquid Chromatography-Mass Spectrometry. Journal of Pineal Research, 18: 28-31.

Feng X, Wanga M, Zhaob Y, Hana P, Ying D 2014. Melatonin from Different Fruit Sources, Functional Roles, and Analytical Methods. Trends in Food Science and Technology, 37 (1): 21-3.

Fernandez-Mar MI, Mateos R, Garcia-Perilla MC, Puertas B, Cantos-Villar E 2012. Bioactive Compounds in Wine: resveratrol, Hydroxytyrosol and melatonin: a Review. Food Chemistry, 130: 797-813.

Fiore DS, Li QR, Leech MJ, Schuster F, Emans N, Fischer R, Schillberg S 2002. Targeting Tryptophan Decarboxylase to Selected Subcellular Compartments of Tobacco Plants Affects Enzyme Stability and in Vivo Function and Leads to A Lesion Mimic Phenotype. Plant Physiology, 129: 1160-1169.

Garcia JJ, Lopez-Pingarron L, Almeida-Souza P, Tres A, Escadero P, Garcia-Gil FA, Tan DX, Reiter RJ, Ramírez JM, Bernal-Pérez M 2014. Protective Effects 
of Melatonin in Reducing Oxidative Stress and in Preserving the Fluidity of Biological Membranes: a Review. Journal of Pineal Research, 56: 225-237.

Garrido M, Paredes SD, Cubero J, Lozano M, Toribio Delgado A F, Munoz JL, , Reiter RJ, Barriga C, Rodríguez AB 2010. Jerte valley cherry enriched diets improve nocturnal rest and increase 6sulfatoxymelatonin and total antioxidant capacity in the urine of middle-aged and elderly humans. Journal of Gerontology: Series A, 65(9), 909e914.

Hardeland R, Backhaus C, Fadav, A 2007. Reactions of the $\mathrm{NO}$ redox forms $\mathrm{NO}+, \mathrm{NO}$ and $\mathrm{HNO}$ (protonated $\mathrm{NO}-$ ) with the Melatonin Metabolite N1-acetyl-5methoxykynuramine. Journal of Pineal Research, 43(4): 382-388.

Hardeland R, Pandi-Perumal SR, Poeggeler B 2000. Melatonin in Plants: Focus on a Vertebrate Night Hormone with Cytoprotective Properties. Functional Plant Science and Biotechnology, 1:32-45.

Hardeland R, Poeggeler B 2012. Melatonin and Synthetic Melatonergic Agonists: Actions and Metabolism in The Central Nervous System. Central Nervous System Agents in Medicinal Chemistry, 12: 189-216.

Hardeland, R 2013. Melatonin and the Theories of Aging: A Critical Appraisal of Melatonin's Role in Antiaging Mechanisms. Journal of Pineal Research, 55: 325-356.

Hattori A, Migitaka H, Masayaki I, Itoh M, Yamamoto K, Ohtani-Kaneko R, Hara M, Suzuki T, Reiter RJ, 1995. Identification of Melatonin in Plant Seed its Effects on Plasma Melatonin Levels and Binding to Melatonin Receptors in Vertebrates. International Journal of Biochemistry and Molecular Biology, 35: 627-634.

Hernández IG, Gomez FJ, Cerutti S, Arana MV, Silva MF 2015. Melatonin in Arabidopsis thaliana Acts as Plant Growth Regulator at Low concentrations and Preserves Seed Viability at High Concentrations. Plant Physiology and Biochemistry, 94: 191-196.

Hernandez-Ruiz J, Arnao MB 2008. Distribution of Melatonin in Different Zones of Lupin and Barley Plants at Different Ages in the Presence and absence of Light. Journal of Agricaltural and Food Chemistry, 56: 10567-10573.

Hernandez-Ruiz J, Cano A, Arnao MB, 2004. Melatonin: Growth-Stimulating Compound Present in Lupin Tissues. Planta, 220: 140-144.

Hernandez-Ruiz J, Cano A, Arnao MB, 2005. Melatonin Acts as a Growth-Stimulating Compound in Some Monocot Species. Journal of Pineal Research, 39: 137142.

Iriti M, Faoro F 2006. Grape Phytochemicals: a Bouquet of Old and New Nutraceuticals for Human Health. Medical Hypotheses, 67: 833-838.

Janas KM, Posmyk MM 2013. Melatonin, an Underestimated Natural Substance with Great Potential for Agricultural Application. Acta Physiologiae Plantarum, 35, 12: 3285-3292.

Jibran R, Hunter DA, Dijkwel PP 2013. Hormonal Regulation of Leaf Senescence through Integration of
Developmental and Stress Signals. Plant Molecular Biology, 82: 547-561.

Kang K, Lee K, Park S, Kim YS, Back, K 2010. Enhanced Production of Melatonin by Ectopic Overexpression of Human Serotonin N-acetyltransferase Plays a Role in Cold Resistance in Transgenic Rice Seedlings. Journal of Pineal Research, 49: 176-182.

Kang S, Kang K, Lee K, Back KW 2008. Characterization of Rice Tryptophan Decarboxylases and Their Direct Involvement in Serotonin Biosynthesis in Transgenic Rice. Planta, 227: 263-272.

Kang, K, Lee, K, Park, S, Byeon, Y, Back KW 2013. Molecular Cloning of Rice Serotonin Nacetyltransferase, The Penultimate Gene in Plant Melatonin Biosynthesis. Journal of Pineal Research, 55: 7-13.

Khan M, Rozhon W, Poppenberger B 2014. The Role of Hormones in the Aging of Plants a Mini-Review. Gerontology, 60: 49-55.

Kolár J, Macháckova I, Eder J, Prinsen E, Van Dongen W, Van Onckelen H, Illnerová H, 1997. Melatonin: Occurence and Daily Rhythm in Chenopodium rubrum. Phytochemistry, 44 (8): 1407-1413.

Kołodziejczyk I, Bałabusta M, Szewczyk R, Posmyk MM 2015.The Levels of Melatonin and İts Metabolites in Conditioned Corn (Zea mays L.) and Cucumber (Cucumis sativus L.) Seeds.

Korkmaz A, Değer Ö, Cuci Y 2014. Profiling the Melatonin Content in Organs of the Pepper Plant during Different Growth Stages. Scientia Horticulturae, 172: 242-247.

Korkmaz A, Yakupoğlu G, Köklü Ş, Cuci Y, Kocaçınar F. 2017a. Determining Diurnal and Seasonal Changes in Tryptophan and Melatonin Content of Eggplant (Solanum melongena L.). Turkish Journal of Botany, 41: 356-366.

Korkmaz, A, Karaca, A, Kocaçmar, F, Cuci, Y 2017b. The Effect of Seed Treatment with Melatonin on Germination and Emergence Performance of Pepper Seeds under Chilling Stress. Tarım Bilimleri Dergisi/Journal of Agricultural Sciences, 23 (2): 167176

Kostopoulou Z, Therios I, Roumeliotis E, Kanellis AK, Molassiotis A 2015. Melatonin Combined with Ascorbic Acid Provides Salt Adaptation in Citrus aurantium L. Seedlings. Plant Physiology and Biochemistry, 86: 15565.

Köklü Ş 2016. Melatoninin Biber Tohumlarının Yaşlanması Üzerine Etkilerinin İncelenmesi. KSÜ. Fen Bil. Ens., Bahçe Bitkileri Bölümü, Yüksek Lisans Tezi, 98s.

Lee HY, Byeon Y, Tan DX, Reiter RJ, Back K 2015. Arabidopsis Seratonin N-acetyltransferase Knockout Mutant Plants Exhibit Decreased Melatonin and Salicylic acid Resulting in susceptibility to an Avirulent Pathogen. Journal of Pineal Research, 58: 291-299.

Lerner AB, Case JD, Takahashi Y, Lee TH, Mori W 1958. Isolation of Melatonin, the Pineal Factor that 
Lightness Melanocytes. Journal of American Chemical Society, 80: 2587-2592.

Li C, Tan DX, Liang D, Chang C, Jia D, Ma F 2015. Melatonin Mediates the Regulation of ABA Metabolism, Free-Radical Scavenging, and Stomatal Behavior in two Malus Species under Drought Stress. Journal of Experimental Botany, 66: 669-680.

Li C, Wang P, Wei Z, Liang D, Liu C, Yin L, Jia D, Fu M, Ma F 2012. The Mitigation Effects of Exogenous Melatonin on Salinity-Induced Stress in Malus hupehensis. Journal of Pineal Research, 53(3): 298-306.

Mukherjee S, David A, Yadav S, Baluška F, Bhatla SC. 2014. Salt Stress-İnduced Seedling Growth İnhibition Coincides with Differential Distribution of Serotonin and Melatonin in Sunflower Seedling Roots and Cotyledons. Physiologia Plantarum, 152: 714-728.

Murch SJ, Alan AR, Cao J, Saxena PK 2009. Melatonin and Serotonin in Fowers and Fruits of Datura metelL. Journal of Pineal Research, 47: 277-283.

Murch SJ, Saxena PK 2002. Melatonin: a Potential Regulator of Plant Growth and Development. Invitro Cellular Developmental Biology Plant, 38: 531-536.

Murch SJ, Saxena PK 2006. A Melatonin-rich Germplasm Line of St John's wort (Hypericum perforatum L.). Journal of Pineal Research, 41: 284- 287.

Okazaki M, Ezura H 2009. Profiling of Melatonin in the Model Tomato (Solanum lycopersicum L.) Cultivar Micro-Tom. Journal of Pineal Research, 46: 338-343.

Paredes SD, Korkmaz A, Manchester LC, Tan DX ve Reiter RJ 2009. Phytomelatonin: a Review. Journal of Pineal Research, 60: 57-69.

Park S, Back K 2012. Melatonin Promotes Seminal Root Elongation and Root Growth in Transgenic Rice After Germination. Journal of Pineal Research, 53: 385-389.

Park S, Kang K, Lee K, Choi D, Kim Y, Back KW 2009. Induction of Serotonin Biosynthesis is Uncoupled from the Coordinated Induction of Tryptophan Biosynthesis in Pepper Fruits (Capsicum annuum) upon Pathogen Infection. Planta, 230: 1197-1206.

Park S, Le TNN, Byeon Y, Kim YS, Back K 2013. Transient Induction of Melatonin Biosynthesis in Rice (Oryza sativa L.) during the Reproductive Stage. Journal of Pineal Research, 55: 40-45.

Park WJ 2011. Melatonin as an Endogenous Plant Regulatory Signal: Debates and Perspectives. Journal Plant Biology, 54: 143-149.

Poeggeler B, Hardeland, R 1994. Detection and Quantification of Melatonin in a Dinoflagellate, Gonyaulax polyedra: Solutions to the Problem of Methoxyindole Destruction in Non-Vertebrate Material. Journal of Pineal Research, 17(1): 1-10.

Posmyk MM, Janas KM, 2009. Melatonin in Plants. Acta Physiologiae Plantarum, 31: 1-11.

Posmyk MM, Kontek R, Janas KM. 2009. Antioxidant Enzymes Activity and Phenolic Compounds Content in Red Cabbage Seedlings Exposed to Copper Stress. Ecotoxicology and Environmental Safety 72: 596-602.
Posmyk MM, Kuran H, Marciniak K, Janas KM 2008. Presowing Seed Treatment with Melatonin Protects Red Cabbage Seedlings Against Toxic Copper Ion Concentrations. Journal of Pineal Research, 45: 24-31.

Reiter RJ 1991. Pineal Melatonin: Cell Biology of its Physiological Interactions. Endocrine Reviews, 12: 151-181.

Reiter RJ 1999. Phytochemicals: Melatonin. In: Frances FJ, ed. Encyclopedia of Food Science and Technology, New York: John Wiley, 1918-1922.

Reiter RJ Manchester LC, Tan DX, 2005. Melatonin in Walnuts: Influence on Levels of Melatonin and Total Antioxidant Capacity of Blood. Nutrition, 21: 920-924.

Reiter RJ, Tan DX, Burkhardt S, Manchester LC 2001. Melatonin in plants. Nutrition Reviews, 59: 286-290.

Reiter, RJ, Tan, DX, Manchester, LC, Simopoulos, AP, Maldonado, MD, Flores LJ, Terron MP 2007. Melatonin in Edible Plants (phytomelatonin); Identification, Concentrations, Bioavailability and Proposed Functions. World Review of Nutrition and Dietetics, 97: 211-230.

Riga P, Medinab S, García-Floresb LA, Gil-Izquierdob A 2014. Melatonin Content of Pepper and Tomato Fruits: Effects of Cultivar and Solar Radiation. Food Chemistry, 156: 347-352

Rodriguez C, Mayo, JC, Sainz, RM, Antolin, I, Herrera, F, Martin V, Reiter RJ 2004. Regulation of Antioxidant Enzymes: A Significant Role for Melatonin. Journal of Pineal Research, 36 (1): 1-9.

Sarropoulou V, Dimassi-Therioru K, Therios I, Koukourikou-Petridou M, 2012. Melatonin Enhances Root Regeneration, Photosynthetic Pigments, Biomass, Total Carbohydrates and Proline Content in the Cherry Rootstock PHL-C (Prunus avium x Prunus cerasus). Plant Physiology and Biochemistry, 61: 162_168.

Sarrou E, Therios I, Dimassi-Therıu K 2014. Melatonin and Other Factors that Promote Rooting and Sprouting of Shoot Cuttings in Punica granatum cv. Wonderful. Turkish Journal of Botany, 38: 293-301.

Shi H, Chan Z 2014. The cysteine2/histidine2-type Transcription Factor Zinc Finger of Arabidopsisthaliana 6-Activated C-Repeat-Binding Factor Pathway is Essential for Melatonin-Mediated Freezing Stress Resistance in Arabidopsis. Journal of Pineal Research, 57: 185-191.

Shi H, Jiang C, Ye T, Tan DX, Reiter RJ, Zhang H, Liu R, Chan Z 2015a. Comparative Physiological, Metabolomic, and Transcriptomic Analyses Reveal Mechanisms of Improved Abiotic Stress Resistance in Bermuda Grass [Cynodon dactylon (L). Pers.] by Exogenous Melatonin. Journal of Experimental Botany, 66: 681-694.

Shi H, Tan DX, Reiter RJ, Ye T, Yang F, Chan Z 2015b. Melatonin Induces Class A1 Heat Shock Factors (HSFA1s) and Their Possible İnvolvement of Thermotolerance in Arabidopsis. Journal of Pineal Research, 58: 335-342. 
Sun Q, Zhang N, Wang J, Zhang H, Li D, Shi J, Li R, Weeda S, Zhao B, Ren S, Guo YD 2015. Melatonin Promotes Ripening and Improves Quality of Tomato Fruit During Postharvest Life. Journal of Experimental Botany, 66: 657-668.

Tal O, Haim A, Harel O, Gerchman Y 2011. Melatonin as an Antioxidant and Its Semi-Lunar Rhythm in Green Macroalga Ulva sp. Journal of Experimental Botany, 62: 1903-1910

Tan DX, Hardeland R, Manchester LC, Korkmaz A, Ma S, Rosales-Corral S, and Reiter RJ 2012. Functional Roles of Melatonin in Plants, and perspectives in Nutritional and Agricultural Science. Journal of Experimental Botany, 63 (2): 577-597.

Tan DX, Manchester LC, Di Mascio P, Martinez GR, Prado FM, Reiter RJ 2007a. Novel Rhythms of N1-acetyl-N2formyl-5-methoxykynuramine and its Precursor Melatonin in Water Hyacinth: Importance for Phytoremediation. The FASEB Journal, 21: 17241729.

Tan DX, Manchester LC, Helton P, Reiter RJ 2007b. Phytoremediative Capacity of Plants Enriched With Melatonin. Plant Signaling and Behavior, 2: 514-516.

Tan DX, Manchester LC, Liu X, Sergio A, Rosales-Corral SA, Acuna-Castroviejo D, Reiter RJ 2013. Mitochondria and Chloroplasts as the Original Sites of Melatonin Synthesis: a Hypothesis Related to Melatonin's Primary Function and Evolution in Eukaryotes. Journal of Pineal Research, 54: 127-138.

Teixeira A, Morfim MP, De Cordova CAS, Charão CCT, De Lima VR, Creczynski-Pasa TB 2003. Melatonin Protects Against Prooxidant Enzymes and Reduces Lipid Peroxidation in Distinct Membranes Induced by the Hydroxyl and Asorbyl Radicals and by Peroxynitrite. Journal of Pineal Research, 35 (4): 262268.

Tettamanti C, Cerabolini B, Gerola P, Conti A 2000. Melatonin Identification in Medicinal Plants. Acta Phytotherapeutica, 3: 137-144.

Uchendu EE, Shukla MR, Reed BM, Saxena PK 2013. Melatonin Enhances the Recovery of Cryopreserved Shoot Tips of American elm (Ulmus americana L.). Journal of Pineal Research, 55: 435-442.

Van Tassel DL, Roberts N, Lewy A, O’Neill SD, 2001. Melatonin in Plant Organs. Journal of Pineal Research, 31: 8-15.

Wang P, Sun X, Li C, Wei Z, Liang D, Ma F 2013. LongTerm Exogenous Application of Melatonin Delays
Drought-Induced Leaf Senescence in Apple. Journal of Pineal Research, 54: 292-302.

Wang P, Sun X, Xie Y, Li M, Chen W, Zhang S, Liang D, Ma F 2014. Melatonin Regulates Proteomic Changes During Leaf Senescence in Malus hupehensis. Journal of Pineal Research, 57: 291-307.

Wei JY, Li WM., Zhou LL, Lu Q-N, He W 2015. Melatonin Induces Apoptosis of Colorectal Cancer Cells Through HDAC4 Nuclear Import Mediated by CaMKII Inactivation. Journal of Pineal Research, 58:4, 429438.

Wolf K, Kolar J,Witters E, Van Dogen W, Van Onckelen H, Machackova I 2001. Daily Profile of Melatonin Levels in Chenopodium rubrum L. Depends on Photoperiod. Journal of Plant Physiology, 158: 14911493.

Xu XD, Sun Y, Guao X, Sun B, Zhang J 2010. Effects of Exogenous Melatonin on Ascorbate Metabolism System in Cucumber Seedlings under High Temperature Stress. Ying Yong Sheng Tai Xue Bao, 21: 2580-2586.

Yakupoğlu G 2016. Patlıcan (Solanum melongena L.)'da Melatonin İçeriğinin ve Üşüme Stresine Karşı Etkisinin Belirlenmesi. KSÜ. Fen Bil. Ens., Bahçe Bitkileri Bölümü, Doktora Tezi, 103s.

Yin L, Wang P, Li M, Ke X, Li C, Liang D, Wu S, Ma X, Li C, Zou Y, Ma F 2013. Exogenous Melatonin Improves Malus Resistance to Marssonina Apple Blotch. Journal of Pineal Research, 54: 426-434.

Zhang N, Zhao B, Zhang HJ, Weeda S, Yang C, Yang ZC, Ren S, Guo YD 2013. Melatonin Promotes WaterStress Tolerance, Lateral Root Formation, and Seed Germination in Cucumber (Cucumis sativus L.). Journal of Pineal Research, 54: 15-23.

Zhao Y, Qi LW, Wang WM, Saxena PK, Liu CZ 2011. Melatonin Improves the Survival of Cryopreserved Callus of Rhodiola crenulata. Journal of Pineal Research, 50: 83-88.

Zhao Y, Tan DX, Lei Q, Chen H, Wang H, Li Q, Gao Y, Kong J 2012. Melatonin and Its Potential Biological Functions in the Fruits of Sweet Cherry. Journal of Pineal Research, 55: 79-88.

Zuo B, Zheng X, He P, Wang L, Lei Q, Feng C, Zhou J, Li Q, Han Z, Kong J 2014. Overexpression of MzASMT Improves Melatonin Production and Enhances Drought Tolerance in Transgenic Arabidopsis thaliana Plants. Journal of Pineal Research, 57:408-417. 